\title{
Discurso de Aceitação do Prémio Leya 2009
}

\author{
Joño Paulo Borges Coelho \\ Escritor Moçambicano
}

RESUMO: JOÃO PAULO BORGES COELHO É UM DOS NOMES MAIS PRESTIGIADOS DA LITERATURA MOÇAMBICANA. AUTOR DOS ROMANCES AS DUAS SOMBRAS DO RIO, (2003), AS VISITAS DO DR. VALDEZ (2004), CRÔNICA DA RUA 513.2 (2006), CAMPO DE TRÂNSITO (2007) E O OLHO DE HERTZOG (2010), ENTRE SUA PRODUÇÃO LITERÁRIA DESTACAM-SE AINDA DOIS VOLUMES DE CONTOS: SETENTRIÃO (2005) E MERIDIÃO (2005). EM 2005, JOÃO PAULO RECEBEU O PRÊMIO JOSÉ CRAVEIRINHA PELO ROMANCE AS VISITAS DO DR. VALDEZ; E EM 2009 FOI O VENCEDOR DO CONCURSO INTERNACIONAL LEYA DE ROMANCES, COM O INÉDITO O OLHO DE HERTZOG, CUJO DISCURSO DE ACEITAÇÃO REPRODUZIMOS AQUI.

ABSTRACT: JOÃO PAULO BORGES COELHO IS ONE OF THE MOST PRESTIGIOUS NAMES OF MOZAMBICAN LITERATURE. HE WROTE THE NOVELS AS DUAS SOMBRAS DO RIO (2003), AS VISITAS DO DR. VALDEZ (2004), CRÔNICA DA RUA 513.2 (2006), CAMPO DE TRÂNSITO (2007), AND O OLHO DE HERTZOG (2010). AMONG HIS LITERARY PRODUCTIONS ONE CAN ALSO DISTINGUISH TWO VOLUMES OF SHORT STORIES: SETENTRIÃO (2005) E MERIDIÃO (2005). IN 2005, JOÃO PAULO WINS THE JOSÉ CRAVEIRINHA PRIZE FOR AS VISITAS DO DR. VALDEZ; AND IN 2009, HE WAS THE WINNER OF THE LEYA 2010 AWARD, WITH THE INEDITED NOVEL O OLHO DE HERTZOG, WHICH THE ACCEPTANCE SPEECH IS PRESENTED HERE.

PALAVRAS-CHAVE: JOÃO PAULO BORGES COELHO, O OLHO DE HERTZOG, PRÊMIO LEYA 2010, DISCURSO DE ACEITAÇÃO.

KEYWORDS: JOÃO PAULO BORGES COELHO, O OLHO DE HERTZOG, LEYA 2010 AWARD, ACCEPTANCE SPEECH. 
Desde tempos recuados que o continente africano se tornou famoso como fonte de matérias-primas. Por elas se matou e se morreu. No princípio foi o ouro da bíblica Ofir e do Mwenemutapa, depois o marfim, o corno de rinoceronte capaz de operar maravilhas no Oriente, e até a energia humana por meio do hediondo comércio de escravos e dos trabalhos forçados. África forneceu, pois, ainda que de forma involuntária e nem sempre com proveito, o combustível das grandes revoluções que fizeram o mundo avançar para aquilo que é hoje. À medida que este avançava, novas matérias-primas nela foram sendo descobertas, assim como se apuraram novas maneiras de as pesquisar: o cacau e a borracha, o petróleo, os diamantes, e até o coltan, o chamado "ouro azul" do sul do Congo, sem o qual os notebooks e os telefones celulares não poderiam funcionar.

Todavia, há uma matéria-prima que desde sempre foi passando despercebida às pesquisas, apesar das esforçadas expedições, da sofisticação das análises e dos testes, dos radares e sondas, enfim, dos satélites.

A matéria-prima a que me refiro, em estado bruto parece uma pedra vulgar em nada distinta das outras pedras. É uma pedra feita das histórias das pessoas deste país, Moçambique, e desta região: dos seus desejos e sonhos, das suas memórias e disputas, dos lugares que habitam e do que fazem no seu dia a dia - enfim, da vida que têm. Talvez (e porque é esta a ordem do mundo enquanto a não conseguirmos mudar), uma pedra mais despojada, mas ainda assim capaz de uma beleza e força singulares.

A par de me desbravar os meus próprios interiores e de me confrontar com a minha própria língua, entendo a escrita literária como o ofício de polir essa pedra. Todavia, dado que para polir cada pedra há primeiro que achá-la, é um ofício que depende também, em grande medida, de mestres garimpeiros. No meu caso tem havido muitos, e quero deixar aqui o nome de três.

O primeiro nome é o de Joaquim Soto, velho camponês das montanhas de Chimanimani, que em certa data do longínquo ano de 1970 que já não consigo precisar, me abrigou de uma chuva torrencial na sua palhota, comigo partilhou o seu milho assado, me ofereceu uma esteira e uma capulana com que passar a noite, ao mesmo tempo que me chamava de seu neto. Revelando-me como vivia e como pensava, entregava-me, com paciência e generosidade infinitas, uma pequena pedra para que eu a polisse. 
O segundo nome é o de Suzé Mantia, que no início da década de 1980, nas aldeias de Mavago, Chilolo e Nkalapa, me ensinou o significado do som de cada tambor e como se montava a armadilha dos pássaros; e me indicou a específica rocha, junto ao rio, onde Samora e Josina se sentaram a descansar, a meio da difícil marcha para sul. Em palavras cantantes de uma minúcia real e ao mesmo tempo imaginária, descreveu-me os acontecimentos todos que couberam dentro desse dia. Lenhador fortíssimo, capaz de derrubar uma árvore grossa com três machadadas, era também o marceneiro exímio que fabricava uma porta com pormenores de espantosa subtileza. Homem de um riso límpido como nunca vi igual, e que infelizmente a malária levou.

O terceiro nome é o de Joaquina Mboa, camponesa e sacerdotisa da aldeia de Bawa, que em meados da década de 1990 me contou a saga do Kanyemba, velha de mais de cem anos, com uma precisão que os documentos de arquivo só vieram comprovar - facto que ainda hoje não deixou de me intrigar.

São inúmeros os exemplos destes meus mestres garimpeiros, tantos que é impossível enumerar. Muitos deles provenientes até da imaginação.

Tal como são inúmeros os mestres ourives que, a partir das pedras que lhes chegaram ou chegam às mãos se têm dedicado a minucioso polimento, com isso ajudando a entender os meandros do ofício de que falo: o Craveirinha, a Noémia, o Knopfli, o Luís Bernardo, o Mia, a Paulina, o Ungulani, o Patraquim, o White, o Suleiman. E, em particular, o jornalista e escritor João Albasini, que me levou pela mão a espreitar segredos antigos desta cidade, alguns dos quais este livro, indiscreto, revela.

Tantos são os mestres ourives que é pois também difícil enumerar. Estes e outros por esse mundo afora, que ao longo dos tempos e nos mais diversos lugares nos têm oferecido à leitura as suas joias particulares. Porque é de leitura que falo, dado que é através dela que podemos chegar à miríade de brilhos e reflexos que de cada joia emana.

Este livro, O Olho de Hertrog, que o júri do Prémio Leya resolveu premiar, conta uma história que curiosamente gira também ao redor de uma pedra. Uma pedra que eu - ourives não de primeira, mas de recente viagem - formalmente hoje devolvo ao lugar onde a fui buscar. Pretendo que o gesto seja um contributo no esforço de tantos mestres garimpeiros e ourives que se dedicam a levantar a parede - que já vai alta - da literatura moçambicana. 
Desejo também que essa parede seja parte integrante e importante daquilo a que podemos chamar simplesmente a Casa da Literatura.

João Paulo Borges Coelho

Maputo, 4 de Março de 2010. 